\title{
Gambaran Perbaikan Kondisi Fungsi Kognitif Pada Lanjut Usia (Lansia) Sebelum Dan Setelah Pemberian Brain Gym : Literature Review
}

\author{
Widya Amalia Chrismonika ${ }^{1 *}$, Lia Dwi Prafitri ${ }^{2}$ \\ 1,2 Program Studi Sarjana Fisioterapi, Universitas Muhammadiyah Pekajangan Pekalongan, \\ Indonesia \\ *email: widyachrismonika@gmail.com
}

\begin{abstract}
The number of elderly in developing countries increases every year. It was predicted by 2050 the number of elderly wiil be 10 million from 22 developing countries. The common health problem facing by elderly is decline in cognitive function due to nervous damage. By giving brain gym, cognitive function in the elderly can be stimulate. The study aimed to describe the improvement of cognitive function in elderly after giving brain gym. The study used a literature review with PICO method. The arcticles were searched trouhgh Google Scholar. The articles should use Mini Mental State Examitation (MMSE) intrusment to measure cognitive function. The result show there was an improvement in the cognitive function in elderly after the brain gym intervention. Gender and age are determinant factors related to cognitive decline in the elderly. There is an improvement in the cognitive function in eldery after the brain gym intervention.Brain gym can be used as a physiotherapy intervention, especially to improve the cognitive fuynction in elderly.
\end{abstract}

Keywords: Brain gym; Cognitive function; Elderly

\begin{abstract}
Abstrak
Jumlah penduduk lansia dinegara berkembang mengalami peningkatan setiap tahun, diprediksi pada tahun 2050 jumlah lansia mencapai 10 juta jiwa dari 22 negara berkembang, salah satu permasalahn kesehatan pada lansia adalah gangguan pada sistem saraf yaitu penurunan kondisi fungsi kognitif, pendekatan fisioterapi untuk perbaikan kondisi fungsi kognitif dilakukan dengan pemberian aktifitas fisik berupa brain gym untuk mempertahankan kemampuan fungsi kognitif yang ada pada lansia dengan memberikan stimulasi pada otak. Penelitian ini bertujuan untuk mengetahui gambaran perbaikan kondisi fungsi kognitif pada lansia setelah pemberian brain gym. Desain penelitian ini menggunakanan analisis literature review dengan metode PICO, pencarian artikel melalui Google Scholar diperoleh 5 artikel yang direview dan menggunakan instrument alat ukur Mini Mental State Examination (MMSE) untuk mengukur fungsi kognitif pada lansia dengan intervensi brain gym. Hasil analisa dari berbagai literature didapatkan bahwa adanya perbaikan kondisi fungsi kognitif pada lansia sebelun dan setelah dilakukan intervensi brain gym. Jenis kelamin perempuan dan rentang usia 55-75 tahun merupakan faktor yang menyebabkan penurunan fungsi kognitif pada lansia. Adanya perbaikan kondisi fungsi kognitif pada lansia sebelum dan setelah dilakukan intervensi brain gym. Brain gym dapat digunakan sebagai intervensi fisioterapi khususunya pasein lansia pada perbaikan kondisi fungsi kognitif.
\end{abstract}

Kata kunci: Brain gym; Fungsi kognitif; Lansia

\section{Pendahuluan}

Populasi jumlah penduduk didunia pada era ageing population dimana jumlah penduduk yang berusia 60 tahun melebihi $7 \%$ dari total jumlah penduduk [10]. Pada tahun 1950 jumlah penduduk lansia di dunia berjumlah 205 juta jiwa dan mengalami peningkatan jumlah penduduk lansia menjadi 810 juta jiwa pada tahun 2012. Angka 


\section{Prosiding Seminar Nasional Kesehatan 2021 Lembaga Penelitian dan Pengabdian Masyarakat Universitas Muhammadiyah Pekajangan Pekalongan}

tersebut diproyeksikan akan mengalami peningkatan jumlah mencapai 2 miliyar pada tahun 2050. Fenomena penuaan penduduk terjadi di semua negara, terlebih pada negara berkembang. Kondisi di tahun 2012, dari 15 negara dengan jumlah penduduk lansia sebesar 10 juta jiwa, 7 tujuh diantaranya negara berkembang. Pada tahun 2050 diprediksikan terdapat 33 negara dengan jumlah lansia mencapai lebih dari 10 juta jiwa, dimana 22 negara diantaranya merupakan negara berkembang [20, p. 12]. Bertambahnya usia individu akan mengalami proses penuaan, yang dapat menyebabkan banyak perubahan secara biologis dan fisiologis, salah satunya pada sistem saraf mengalami penurunan fungsi otak dan penurunan fungsi kognitif pada lansia [19, p. 543]. Proses penuaan otak, mengakibatkan penurunan jumlah neuron terjadi secara bertahap yang meliputi area girus temporal superior (area yang paling cepat kehilangan neuron), girus presentralis dan area striata. Secara patologis penurunan jumlah neuron akan mengakibatkan timbulnya ganguan kognitif atau fungsi kognitif dan perilaku [15].

Penurunan daya ingat atau fungsi kognitif yaitu menurunnya kemampuan dalam berpikir atau mengingat kembali peristiwa yang telah terjadi dalam jangka panjang dan pendek, hal tersebut sering terjadi pada lansia [13]. Penurunan fungsi kognitif dapat disebakan oleh berbagai faktor, baik dari individu maupun lingkungan. Faktor individu meliputi usia, jenis kelamin, tingkat pendidikan, faktor genetik, dan riwayat penyakit.

Sedangkan faktor lingkungan meliputi hubungan/keterlibatan sosial (social engagement) dan aktivitas, baik aktivitas fisik maupun aktivitas kognitif [21, p. 7].

Intervensi pada perbaikan fungsi kognitif terdapat dua cara yaitu salah satunya terapi non farmakalogi. Terapi non farmakologi yang digunakan untuk menstimulus otak yang bertujuan meningkatkan fungsi kognitif pada lansia dengan melakukan aktivitas fisik yaitu olahraga brain gym (senam otak) untuk mempertahankan kemampuan yang ada pada lansia dengan memberikan stimulasi pada otak [12]. Brain gym merupakan serangkaian gerakan yang dapat menyeimbangkan setiap anatomi otak, dapat menarik keluar tingkat kosentrasi otak, dan sebagai jalan keluar bagian otak yang terhambat agar dapat berfungsi maksimal [18, p. 192].

Penelitian yang dilakukan oleh Setiawan (2014) menyatakan bahwa didapatkan terjadinya perubahan skor fungsi kognitif secara bermakna, setelah dilakukan pemberian brain gym dengan hasil skor nilai kognitif ringan. Didukung dengan hasil penelitian lainnya, yang didapatkan adanya pengaruh brain gym terhadap perbaikan kognitif lansia brain gym otak dikarenakan brain gym menyelaraskan aktivitas kemampuan dan berpikir pada saat yang sama meningkatkan keseimbangan dan harmonisasi antara kontrol emosi dan logika, mengoptimalkan fungsi indera, menjaga kelenturan dan keseimbangan tubuh, meningkatkan daya ingat, meningkatkan ketajaman, pendengaran, mengurangi kesalahan membaca, daya ingat, dan kemampuan komprehensif dalam kelompok penggunaan bahasa (Festi, 2010). Untuk mengetahui gambaran terapi brain $\mathrm{gym}$ terhadap perbaikan kondisi fungsi kognitif pada lansia, maka penulis mengambil judul "Gambaran Perbaikan Kondisi Fungsi Kognitif Pada Lanjut Usia (Lansia) Sebelum dan Setelah Pemberian Brain Gym : Literatur Review'. 


\section{Prosiding Seminar Nasional Kesehatan Lembaga Penelitian dan Pengabdian Masyarakat Universitas Muhammadiyah Pekajangan Pekalongan}

\section{Literature Review}

Tabel 2.1 Analisa Literature Review

\begin{tabular}{|c|c|c|c|c|c|c|c|}
\hline \multicolumn{3}{|c|}{ Sumber } & \multirow[t]{2}{*}{ Perpose } & \multicolumn{3}{|c|}{ Metodologi } & \multirow[t]{2}{*}{ Temuan } \\
\hline $\begin{array}{c}\text { Penulis } \\
\text { (Authors) }\end{array}$ & $\begin{array}{l}\text { Tahun } \\
\text { (Year) }\end{array}$ & Journal & & Design & Sample & $\begin{array}{c}\text { Instrumen } \\
\text { Penelitian/ } \\
\text { Data } \\
\text { Collection tool } \\
\text { (s) }\end{array}$ & \\
\hline $\begin{array}{l}\text { Amtonis \& } \\
\text { Fata }\end{array}$ & 2014 & $\begin{array}{l}\text { Jurnal Ners } \\
\text { dan } \\
\text { Kebidanan } \\
\text { Vol. 01, no. } \\
\text { 02, hh. 90- } \\
\text { 96, Juli 2014 }\end{array}$ & $\begin{array}{l}\text { Menjelaskan } \\
\text { pengaruh } \\
\text { senam otak } \\
\text { terhadap } \\
\text { peningkatan } \\
\text { fungsi kognitif } \\
\text { pada lansia di } \\
\text { UPT PSLU Blitar }\end{array}$ & $\begin{array}{l}\text { Pre post test } \\
\text { one group } \\
\text { design }\end{array}$ & $\begin{array}{l}\mathrm{N}=20 ; \text { Iansia } \\
\text { berusia usia } \\
60-74 \text { tahun. }\end{array}$ & $\begin{array}{l}\text { Mini Mental } \\
\text { Satate } \\
\text { Examitation } \\
\text { (MMSE) }\end{array}$ & 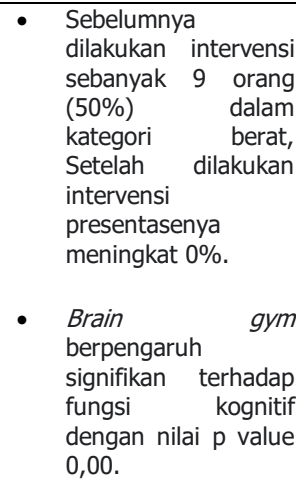 \\
\hline $\begin{array}{l}\text { Yuliati \& } \\
\text { Hidaayah }\end{array}$ & 2017 & $\begin{array}{l}\text { Jurnal Ilmiah } \\
\text { Kesehatan, } \\
\text { Vol. 10, No. } \\
\text { 01, hh. 88-95 } \\
\text { Februari } \\
2017 .\end{array}$ & \begin{tabular}{lr}
\multicolumn{2}{l}{ Mengetahui } \\
pengaruh \\
senam otak \\
terhadap fungsi \\
kognitif pada \\
lansia di RT 03 \\
RW 01 \\
Kelurahan \\
Tandes
\end{tabular} & $\begin{array}{l}\text { Pre- } \\
\text { Eksperimental; } \\
\text { one group } \\
\text { pre- post test, }\end{array}$ & $\begin{array}{l}\mathrm{N}=6 \text {; lansia } \\
\text { berusia usia } \\
60-74 \text { tahun }\end{array}$ & $\begin{array}{l}\text { Mini Mental } \\
\text { Satate } \\
\text { Examitation } \\
\text { (MMSE) }\end{array}$ & $\begin{array}{l}\text { - Lansia setelah } \\
\text { dilakukan intervensi } \\
\text { sebagaian besar tidak } \\
\text { mengalami gangguan } \\
\text { kognitif. } \\
\text { - Brain } \\
\text { berpengaruh gym } \\
\text { terhadap fungsi } \\
\text { kognitif dengan nilai } p \\
\text { value } 0,014\end{array}$ \\
\hline $\begin{array}{l}\text { Azizah, } \\
\text { Martiana \& } \\
\text { Soedirham }\end{array}$ & 2017 & $\begin{array}{l}\text { International } \\
\text { Journal Of } \\
\text { Nursing and } \\
\text { Midwifery , } \\
\text { Volume 01, } \\
\text { Issue 01, hh. } \\
\text { 26-31, May- } \\
\text { August } 2017\end{array}$ & $\begin{array}{l}\text { Menganalisis } \\
\text { efektivitas } \\
\text { senam otak } \\
\text { dalam } \\
\text { meningkatkan } \\
\text { fungsi kognitif } \\
\text { dan penurunan } \\
\text { tingkat stres } \\
\text { lansia. }\end{array}$ & $\begin{array}{l}\text { Pre- } \\
\text { Eksperimental; } \\
\text { one group } \\
\text { pre- post test, }\end{array}$ & $\begin{array}{l}\mathrm{N}=35 ; \\
\text { yang berusia } \\
60-75 \text { tahun }\end{array}$ & $\begin{array}{l}\text { Mini Mental } \\
\text { Satate } \\
\text { Examitation } \\
\text { (MMSE) }\end{array}$ & 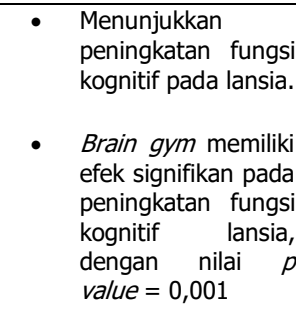 \\
\hline $\begin{array}{l}\text { Amila \& } \\
\text { Syapitri }\end{array}$ & 2018 & $\begin{array}{l}\text { Jurnal } \\
\text { Mutiara Ners, } \\
\text { Vo. 01, no. } \\
01, \text { hh. 44- } \\
\text { 46, Januari } \\
2018\end{array}$ & $\begin{array}{l}\text { Mengidentifikasi } \\
\text { adanya } \\
\text { pengaruh } \\
\text { senam otak } \\
\text { terhadap fungsi } \\
\text { kognitif di } \\
\text { Puskesmas } \\
\text { Rantang } \\
\text { Medan. }\end{array}$ & $\begin{array}{l}\text { Quasi } \\
\text { eksperimental; } \\
\text { pendekatan } \\
\text { one groupe } \\
\text { and post test } \\
\text { Design }\end{array}$ & $\begin{array}{l}\mathrm{N}=21 \text {; lansia } \\
\text { yang berusia } \\
55-69 \text { tahun }\end{array}$ & $\begin{array}{l}\text { Mini Mental } \\
\text { Satate } \\
\text { Examitation } \\
\text { (MMSE) }\end{array}$ & 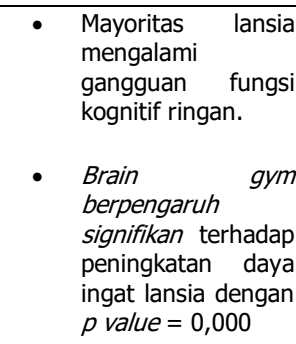 \\
\hline $\begin{array}{l}\text { Lestari, } \\
\text { Azizah1 \& } \\
\text { Khusniyati }\end{array}$ & 2020 & $\begin{array}{l}\text { Jurnal } \\
\text { IImiah } \\
\text { Kesehata } \\
\text { Rustida, } \\
\text { Volume 07, } \\
\text { No. 02, hh. } \\
125-132 \text {, } \\
\text { Juli } 2020\end{array}$ & $\begin{array}{l}\text { Mengetahui } \\
\text { pengaruh } \\
\text { brain gym } \\
\text { terhadap } \\
\text { fungsi kognitif } \\
\text { lansia. }\end{array}$ & $\begin{array}{l}\text { Pra } \\
\text { eksperimental, } \\
\text { pretest-post } \\
\text { test one group } \\
\text { design. }\end{array}$ & $\begin{array}{l}\mathrm{N}=13 \text {; lansia } \\
\text { berusia } 60- \\
74 \text { tahun }\end{array}$ & $\begin{array}{l}\text { Mini Mental } \\
\text { Satate } \\
\text { Examitation } \\
\text { (MMSE) }\end{array}$ & $\begin{array}{l}\text { Terdapat pengaruh yang } \\
\text { lemah fungsi kognitif } \\
\text { lansia dari brain gym } \\
\text { dengan } p \text { value } 0,046 \text {, } \\
\text { dikarenakan hanya } 4 \text { dari } \\
13 \text { lansia yang terjadi } \\
\text { peningkatan fungsi } \\
\text { kognitif. }\end{array}$ \\
\hline
\end{tabular}




\section{Prosiding Seminar Nasional Kesehatan Lembaga Penelitian dan Pengabdian Masyarakat Universitas Muhammadiyah Pekajangan Pekalongan}

\section{Metode}

\section{Pemilihan artikel}

Desain penelitian ini menggunakan analisis literature review dengan menggunakan metode PICO yang terdiri dari patient/population, intervenstion, comporator/control dan outcome.

\section{Identifikasi data/esktrasi data}

Penelitian ini menggunakan penelusuran literature melalui databse online yaitu Google Scholar dengan kata kunci : "Senam otak, fungsi kognitif, lansia" atau "Cognitive function, brain gym, elderly". Identifikasi data diperoleh 5 artikel penelitian yang telah memenuhi kreteria inklus dan layak digunakan untuk analisa lebih lanjut.

\section{Analisa data}

Penelitian ini menggunakan teknik analisis PICO yang berfungsi mendeskripsikan suatu variable yaitu brain gym pada fungsi kognitif lansia, dalam pemilihan artikel ini telah ditelaah, disuse, dan dideskripsikan sesuai dengan tujuan penelitian.

\section{Hasil dan Pembahasan}

\section{Hasil}

a. Karakteristik Responden Berdasarkan Jenis kelamin dan Usia

Tabel 4.1 Hasil Analisa Literature Review Berdasarkan Karakteristik Responden $(\mathrm{N}=93)$

\begin{tabular}{lcccc}
\hline \multicolumn{1}{c}{ Artikel } & \multicolumn{5}{c}{ Karakteristik Responden } \\
\hline \multicolumn{1}{c}{ Penulis } & N & L & P & \\
\hline & 18 & 6 & 12 & $60-74$ \\
\hline Amtonis, Fata (2014) & 6 & 1 & 5 & $60-69$ \\
\hline Yulianti, Hidayah (2017) & 35 & NM & NM & $60-75$ \\
\hline $\begin{array}{l}\text { Azizah, Martiana, Soedirman } \\
\text { (2017) }\end{array}$ & 21 & NM & NM & $55-69$ \\
\hline Amila, Syapitri (2018) & 13 & 6 & 7 & $60-74$ \\
\hline Lestari, Azizah, Khusniyati (2020) & & & & \\
\hline (NM= Not mention in articel) & & &
\end{tabular}

b. Perbaikan Fungsi Kognitif

Tabel 4.2 Hasil analisa literature review perbaikan kondisi fungsi kognitif pada lansia sebelum dan setelah pemberian brain gym

\begin{tabular}{|c|c|c|c|c|c|c|c|c|c|c|}
\hline \multirow[t]{3}{*}{ Penulis } & \multirow[t]{3}{*}{$\mathbf{N}$} & \multirow[t]{3}{*}{ Durasi } & \multicolumn{8}{|c|}{ Hasil } \\
\hline & & & \multicolumn{4}{|c|}{ Sebelum } & \multicolumn{4}{|c|}{ Setelah } \\
\hline & & & Normal & Ringan & Sedang & Berat & Normal & Ringan & Sedang & Berat \\
\hline $\begin{array}{l}\text { Amtonis, } \\
\text { Fata (2014) }\end{array}$ & 18 & $\begin{array}{l}\text { Setiap pagi, } \\
20 \text { menit } \\
\text { selama } 3 \\
\text { minggu. }\end{array}$ & 2 & 7 & 0 & 9 & 15 & 3 & 0 & 0 \\
\hline $\begin{array}{l}\text { Yulianti, } \\
\text { Hidyaah } \\
(2017)\end{array}$ & 6 & $\begin{array}{l}3 \text { kali } \\
\text { seminggu, } \\
20 \text { menit } \\
\text { selama } 1 \\
\text { bulan. }\end{array}$ & 0 & 0 & 4 & 2 & 4 & 0 & 2 & 0 \\
\hline
\end{tabular}




\section{Prosiding Seminar Nasional Kesehatan Lembaga Penelitian dan Pengabdian Masyarakat Universitas Muhammadiyah Pekajangan Pekalongan}

\begin{tabular}{|c|c|c|c|c|c|c|c|c|c|c|}
\hline \multirow[t]{3}{*}{ Penulis } & \multirow[t]{3}{*}{$\mathbf{N}$} & \multirow[t]{3}{*}{ Durasi } & \multicolumn{8}{|c|}{ Hasil } \\
\hline & & & \multicolumn{4}{|c|}{$\begin{array}{l}\text { Sebelum } \\
\end{array}$} & \multicolumn{4}{|c|}{ Setelah } \\
\hline & & & Normal & Ringan & Sedang & Berat & Normal & Ringan & Sedang & Berat \\
\hline $\begin{array}{l}\text { Azizah, } \\
\text { Martiana, } \\
\text { Soedirman } \\
\text { (2017) }\end{array}$ & 35 & $\begin{array}{l}2 \text { kali } \\
\text { seminggu, } \\
15 \text { menit } \\
\text { selama } 4 \\
\text { minggu. }\end{array}$ & 8 & 21 & 6 & 0 & 14 & 16 & 5 & 0 \\
\hline $\begin{array}{l}\text { Amila, } \\
\text { Syapitri } \\
\text { (2018) }\end{array}$ & 21 & $\begin{array}{l}\text { Setiap pagi, } \\
10-15 \text { menit, } \\
4 \text { kali } \\
\text { seminggu } \\
\text { selama } 2 \\
\text { minggu. }\end{array}$ & 0 & 18 & 3 & 0 & 5 & 14 & 2 & 0 \\
\hline $\begin{array}{l}\text { Lestari, } \\
\text { Azizah, } \\
\text { Khusniyati } \\
(2020)\end{array}$ & 13 & $\begin{array}{l}3 \text { kali } \\
\text { seminggu, } \\
15 \text { menit, } \\
\text { selama } 1 \\
\text { minggu. }\end{array}$ & 0 & 11 & 0 & 2 & 4 & 7 & 0 & 2 \\
\hline Jumlah & 93 & & 10 & 57 & 13 & 13 & 42 & 40 & 9 & 2 \\
\hline
\end{tabular}

\section{Pembahasan}

a. Karakteristik Responden Berdasarkan Jenis Kelamin dan Usia

Hasil analisa literature review dari artikel yang mencantumkan jenis kelamin diketahui bahwa dari artikel Amtonis \& Fata (2014), Yulianti \& Hidyaah (2017) dan Lestari, Azizah dan Khusniyati (2020) lebih banyak responden berjenis kelamin perempuan, dengan rentang usia dari 5 artikel yaitu 55-74 tahun. Penurunan fungsi kognitif pada lansia dipengaruhi oleh faktor jenis kelamin dan usia [21]. Jenis kelamin perempuan lebih berisiko mengalami gangguan atau penurunan fungsi kognitif dibandingkan jenis kelamin laki-laki. Kondisi ini dikaitkan dengan adanya peranan level hormon seks endogen dalam perubahan fungsi kognitif pada perempuan Selain itu, terdapat adanya reseptor estrogen seperti hipokampus dalam area otak memiliki peran dalam fungsi belajar dan memori. Menurut teori level ekstradiol dalam tubuh manusia berhubungan dengan fungsi kognitif dan memori verbal pada manusia. Ekstradiol diperkirakan memiliki sifat neuroprotektif yaitu dapat membatasi kerusakan akibat stress oksidatif serta melindung sel saraf [1].

Rentang usia berpengaruh terhadap penurunan fungsi kognitif. Usia yang semakin tua menyebabkan perubahan struktur anatomi otak, diantaranya otak mengalami atrofi, penurunan massa sekitar 10-20\%, perubahan biokimiawi pada susunan saraf pusat, sehingga mengalami gangguan pada sinaps dan daya hantar implus antar sel saraf [14]. Penurunan fungsi kognitif terjadi seiring dengan peningkatan usia, dapat disimpulkan bahwa kerusakan fungsi organ akibat penuaan Gillis et al. [8].

b. Perbaikan fungsi kognitif pada lanjut usia

1) Fungsi kognitif sebelum diberikan brain gym

Fungsi kognitif lanjut usia dari hasi analisa dari 5 artikel sebelum dilakukan intervensi brain gym, didapatkan bahwa dari 93 responden, hasil kategori fungsi kognitif normal 10 responden, paling banyak dalam mayoritas status fungsi kognitif kategori ringan 57 responden, Sedangkan responden dengan status fungsi kognitif sedang 13 responden dan kategori fungsi kognitif berat 13 responden. Sistem saraf pusat pada lansia mengalami penurunan koordinasi dan penurunan 


\section{Prosiding Seminar Nasional Kesehatan $\mid 2021$ \\ Lembaga Penelitian dan Pengabdian Masyarakat Universitas Muhammadiyah Pekajangan Pekalongan}

kemampuan fungsi kognitf disebabkan susunan saraf pusat mengalami perubahan morfologi dan biokomia. Otak lansia mengalami penurunan massa otak dikarenakan berkurangnya kandungan protein dan lemak pada otak sehingga otak menjadi ringan. Terjadi perubahan pada akson, badan sel saraf, dan dendrite yang berfungsi sebagai sarana untuk komunikasi antar sel saraf mengalami perubahan menjadi lebih tipis dan terjadi penurunan daya hantar sel saraf sehingga gerakan menjadi lamban [5].

Hasil analisa 3 dari 5 artikel didaptakan bahwa berdasarkan karateristik jenis kelamin didapatkan jumlah jenis kelamin perempuan lebih banyak dari jenis kelamin laki-laki. Hasil penelitian ini didukung oleh pendapat Pinilih, Astuti dan Rini (2017) mengatakan bahwa responden perempuan berisiko tinggi mengalami penurunan fungsi kognitif. Hal ini disebabkan hormon endogen pada wanita berperan penting dalam otak, mampu mengubah fungsi belajar dan memori sehingga wanita lebih beresiko untuk mengalami penurunan fungsi kognitif. Hasil analisa karakteritik berdasarkan rentang usia usia yang didapatkan dari 5 artikel yaitu 55-75 tahun, dimana responden mengalami penurunan fungsi kognitif. Hasil penelitian ini didukung oleh Fitriana (2015) pertambahan usia terjadi perubahan pada sistem otak mengalami kemunduran daya ingat dan intelegensi dasar. Kemunduran daya ingant berupa penurunan kemampuan proses mencari kembali informasi yang telah tersimpan didalam memori otak dan penurunan kemampuan penamaan (naming). Sedangkan, intelegensi dasar berupa penurunan fungsi otak bagian kanan, yaitu kesulitan dalam komunikasi nonverbal, seperti pemecahan masalah, kesulitan dalam pemusatan perhatian dan konsentrasi.

\section{2) Gambaran Perbaikan Fungsi kognitif setelah diberikan brain gym}

Hasil dari table 3. terdapat 4 artikel yang menunjukan adanya pengaruh brain gym terhadap perbaikan fungsi kognitif pada lanjut usia setelah pemberian brain gym, semakin tinggi dosis yang diberikan dan dilakukan terus menurus secara rutin, hasil yang didapatkan semakin baik. Hal ini dapat dilihat dari penelitian Amtonis \& Fata (2014) dengan memberikan dosis setiap pagi, 20 menit setiap pertemuan, selama 3 minggu. Karena gerakan brain gym merangsang kedua belahan otak dan mengaktifkan tiga dimensi otak, pada dimensi pemusatan memperlancar sirkulasi darah dan oksigen menuju ke otak. Dimensi pemfokusan melepaskan hambatan fokus dan memperbaiki penurunan daya ingat.

Ditemukan satu artikel yang menyatakan bahwa brain gym terdapat pengaruh lemah terhadap perbaikan kondisi fungsi kognitif pada lanjut usia setelah dilakukan intervensi dapat dilihat dari penelitian Lestari, Azizah dan Khusniyati (2020) dengan dosis 3 kali seminggu, 15 menit setiap pertemuan, selama 1 minggu, ditemukan hasil 4 dari 13 responden yang mengalami perbaikan fungsi kognitif. 9 responden tidak mengalami perubahan perbaikan fungsi kognitif dikarenakan waktu pelaksanaan yang singkat dan responden tidak mengikuti gerakan senam dengan baik. Proses perbaikan fungsi kognitif pada lansia membutuhkan waktu yang lama dan dilakukan secara rutin. 


\section{Prosiding Seminar Nasional Kesehatan Lembaga Penelitian dan Pengabdian Masyarakat Universitas Muhammadiyah Pekajangan Pekalongan}

\section{Kesimpulan}

Hasil analisia dari jenis kelamin perempuan dan rentang usia 55-75 tahun merupakan faktor yang menyebabkan penurunan fungsi kognitif pada lansia. Hasil literature review didapatkan adanya perbaikan kondisi fungsi kognitif pada lansia sebelum dan setelah dilakukan intervensi brain gym.

\section{Referensi}

[1] Agoes Achdiat, Lestari Retno, and Alfaruqi Saifullah, "Pengaruh terapi latihan otak (brain age) terhadap peningkatan fungsi kognitif pada lansia", MNJ, vol. 2, no. 3, pp. 64-70, 2016.

[2] Amila and Syapitri Henny, "Pengaruh senam otak terhadap fungsi kognitif dan kualitas tidur pada lansia di pukesmas Rantang Medan", Jurnal Mutiara Ners, vo. 1, no. 1, pp. 44-56, 2018.

[3] Amtonis Inosensia and Fata Ulfa Husnul, "Pengaruh senam otak terhadap peningkagtan fungsi kognitif", Jurnal ners kebidanan, vo. 1, no 2, pp. 90-96, 2017.

[4] L. M. Azizah, T. Martiana, and O. Soedirman, ${ }^{\prime n}$ The improvement of cognitive function and decrease the level of stress in the elderly with brain gym", International Journing Of Nursing and Midwifery, vol. 1, no. 1, pp. 26-31, 2017.

[5] Dewi, S, R, "Pengaruh senam otak dan bermin puzzle terhadap fungsi kognitif lansia di PLTU Jember", Jurnal Kesehatan Primer, vol. 1, no. 1, pp. 64-69, 2016.

[6] Festi Pipit, 2011, "Pengaruh brain gym terhadap peningkatan fungsi kognitif lansia dikarang werdha peneleh Surabay", Jurnal Kesehatan, 2011.

[7] Fitriana, L, A,"Hubungan kemampuan kognitif dengan daya jantung paru, kelentukan, dan keseimbangan pada waniti lanjut usia" Jurnal Kepelatihan Olahraga, vol. 7, no. 2, pp. 69-81, 2015.

[8] C. Gillis, F. Mirzei, M. Potashman, M. A. Ikram, and N. Msejeian, "The incidence of mild cognitive impairment : a systematic review and data synthesis, Alzheimers \& Dementia", no. 11, pp. 248-256, 2019.

[9] B. Gossard, "Age related cognitive decline", An article from life extension faudation, 2013.

[10] Kementerian Kesehatan RI. (2017). Profil Kesehatan Indonesia Tahun 2016. Jakarta: Kemenkes RI.

[11] Lestari Maria Suci, Azizah Lilik Ma'rifatul, and Khusniyati Etik, "Pengaruh brain gym terhadap fungsi kognitif pada lansia werdha Majapahit Kabupaten Mojokerto", Jurnal IImiah Kesehatan Rusdita, vo. 7, no. 02, pp. 25-132, 2020.

[12] Markam, S. (2005). Latihan vitalisasi otak (senam untuk kebugaran fisik dan otak). Jakarta: Grasindo.

[13] Maryam, R.S., et al. (2008). Mengenal usia lanjut dan perawatnnya. Jakarta: Salemba Medika. 


\section{Prosiding Seminar Nasional Kesehatan Lembaga Penelitian dan Pengabdian Masyarakat Universitas Muhammadiyah Pekajangan Pekalongan}

[14] Nugroho, J. (2014). Keperawatan Gerontik. Jakarta: EGC.

[15] Parreta, L. (2005). Makanan untuk otak. panduan penting untuk meningkatkan kemampuan otak anda. Jakarta : Erlangga.

[16] Pinilih, S, S, Astuti, R, T and Rini, D, R 2017, 'Hubungan antara lifestyle dengan fungsi kofnitif pada lansia', Journal of Holistic Nursing Science, vol. 5. no. 1, hh. 25-35.

[17] Setiawan Rochmad Agus (2014). "Pengaruh senam otak dengan fungsi kognitif lansia demensia di panti wredha darma bakti kasih Surakarta". Skripsi Program Studi S-1 Keperawatan. Stikes Kusuma Husada. Surakarta.

[18] Surahmat Raden and Novitalia 2017, "Pengaruh terapi senam otak terhadap tingkat kognitif lansia yang mengalami demensia di panti sosial tresna werdha warga tama inderalaya", Majalah kesehatan sriwijaya, 4 Oktober, p. 192.

[19] V. Trouillet, L. M. Doan-Va-Hay, S. Martin, and M. Launay, "Impact of Age, and Cognitive and coping resources on coping", Canadian Journal on Aging, vol. 30, no. 4, pp. 541-550, 2011.

[20] UNFPA (2012). Ageing in The Twenty First Century : $A$ Celebration and $A$ Challenge. New York: UNFPA.

[21] Wreksoatmodjo, B, R, "Pengaruh aktivitas fisik terhadap fungsi kognitif lanjut usia di Jakarta Barat', Cermin Dunia Kedokteran, vol. 43, no. 1, pp. 7-12, 2016.

[22] Yulianti and Hidayah $\mathrm{Nu}$, "Pengaruh senam otak (brain gym) terhadap fungsi kognitif pada lansia di rt 03 rw 07 Kelurahan Tandes Surabaya", Jurnal Ilmiah Kesehatan, vol. 10, no. 1, pp. 88-95, 2017. 